ADDIN, Vol. 10, No. 1, Februari 2016

\title{
ISLAM FORMALIS VERSUS ISLAM LOKALIS: \\ Studi Pribumisasi Islam Walisongo dan Kiai Ciganjur
}

\section{Ubaidillah Achmad}

UIN Walisongo Semarang, Jawa Tengah, Indonesia

ubaidillahachmada@gmail.com

\begin{abstract}
Abstrak
Dalam tulisan ini, penulis ingin menyampaikan studi atau keunikan tentang Walisongo dan Kiai Ciganjur di tengah diskursus antara dua gerakan Islam, yaitu pabam Islam formalis dan paham Islam lokalis. Dalam dua klasifikasi model keberagamaan ini, penulis akan menguraikan alasan kehadiran Walisongo dan Kiai Ciganjur memperkuat perspektif Islam lokalis. Hal ini terbaca dari istilah pribumisasi Islam yang menjadi model keberagamaan Walisongo dan terbaca dari istilah dinamisasi Islam yang menjadi model keberagamaan Kiai Ciganjur. Kedua istilah inilah yang menguatkan simpulan penulis terhadap kehadiran Walisongo dan Kiai Ciganjur sebagai tokoh yang berpaham Islam lokalis. Hal yang membedakan antara kedua paham ini adalah adanya paham Islam lokalis yang menerima kebenaran yang bersifat universal. Sementara, Islam formalis membatasi pandangan dan sikeap pada simbol kehendak kuasa dan sistem komunalisme agama.
\end{abstract}

Kata Kunci: Walisongo, Kiai Ciganjur, Islam Formalis, Islam Lokalis, Pribumisasi, Dinamisasi. 
Ubaidillah Achmad

\section{Abstract}

THE FORMALIST VERSUS LOCALIST: WALISONGO AND KIAI CIGANJUR ISLAMIZATION ISLAM STUDIES: In this article, the uniqueness of Walisongo and Kiai Ciganjur in the middle of the discourse between the two Islamic movements, namely Islam formalist understanding and localist Islam. In the two religiosity classification model, it is described the reason for the presence of Walisongo and Kiai Ciganjur strengthen lokalist Islamic perspective. This is read from the pribumisasi Islam as a Walisongo religiosity model and the term Islam dinamization as Kiai Ciganjur religiousity model. This is the two terms that reinforces the conclusions of the author of the presence of Walisongo and Kiai Ciganjur as Islamic local prominent. It distinguishes between the two understands this is the existence of localist Islam ideologies who receive the truth which are universal. Meanwhile, Islam formalist limit the views and attitudes on the symbol of the will of the power and the religion comunalism system.

Keywords: Walisongo, Kiai Ciganjur, Formalist, Localist, Indegeneousation, Dinamization.

\section{A. Pendahuluan}

Penelitian ini dilatarbelakangi adanya persoalan kekerasan atas nama agama. Beberapa kasus tertentu telah menggunakan simbol agama Islam. Misalnya, kekerasan dilakukan oleh kelompok Gafatar, FPI, jaringan atas nama Jama'ah Islamiyah, dan beberapa konflik keberagamaan yang disebabkan oleh perbedaan paham, politik, komunitas beragama, dan jaringan terorisme dunia. Fenomena ini yang memunculkan tema kajian dan penelitian tentang agama dan radikalisme. Fenomena ini sekaligus menegaskan perbedaan kata radikal perspektif filsafat yang mengarah pada upaya berpikir mendalam dan radikalisme perspektif paham gerakan yang mengarah pada upaya memaksa kepada orang lain untuk menguatkan akar-akar ideologis dan politis. Adanya fenomena gerakan radikal atas nama Islam merupakan fenomena yang memerlukan kajian dan penelitian yang tidak bisa diabaikan oleh para akademisi. Hasil kajian ini untuk menunjukkan visi peradaban Islam yang bersumber dari tradisi nubuwah dan menunjukkan visi peradaban Islam yang 
telah terdistorsi oleh kepentingan komunal. Karenanya, penelitian ini bertujuan menegaskan kembali visi peradaban Islam dan menegaskan penyimpangan perilaku kekerasan atas nama Islam.

Dalam penelitian ini akan menyampaikan posisi Walisongo dan Kiai Ciganjur di tengah menguatnya isu perilaku kekerasan atas nama agama Islam. Karenanya, penelitian ini akan membuktikan fungsi teks kewahyuan dan karya-karya tentang keberagamaan masyarakat muslim dan mengapa terjadi dua gerakan pemahaman umat Islam. ${ }^{1}$ Kedua gerakan pemahaman ini berbeda dalam memahami Islam. Secara spesifik, penelitian ini akan membahas tentang keberagamaan Walisongo dan Kiai Ciganjur yang telah berhasil menunjukkan makna Islam rặ matan li al-'alamin dan kearifan lokal. Sebelum mengkaji keunikan Walisongo dan Kiai Ciganjur, penulis akan memaparkan peta perkembangan pemikiran Islam yang penulis klasifikasi menjadi Islam formalis dan Islam lokalis.

Dari pemetaan ini, penulis akan mengkaji peran dan posisi Walisongo dan Kiai Ciganjur. Dalam upaya untuk memudahkan mengkaji tema ini, penulis menggunakan pendekatan psikologis dan filosofis. Pendekatan ini didasarkan pada model penelitian kualitatif yang menguatkan peran penulis membentuk perspektif terhadap objek yang dipahami melalui pendekatan yang digunakan dalam penelitian ini. ${ }^{2}$ Penggunaan kedua pendekatan ini bertujuan untuk memahami peta perkembangan pemikiran Islam. Karenanya, teks klasik sebagai sumber pemikiran Islam akan penulis pahami dengan metode hermeneutika dan fenomenologi. ${ }^{3}$ Sehubungan dengan kompleksitas persoalan radikalisme di tengah aktivitas keberagamaan ini, penulis akan memfokuskan pada rumusan permasalahan: ada dengan agama Islam? bagaimana memahami visi peradaban Islam di tengah

${ }^{1}$ Bungaran Antonius Simanjutak, Metode Penelitian Sosial (Jakarta: Yayasan Obor Indonesia, 2014).

${ }^{2}$ Septiawan Santana K., Menulis Ilmiah: Metodologi Penelitian Kualitatif (Jakarta: Yayasan Obor Indonesia, 2010).

${ }^{3}$ Roy J. Howard, Hermeneutika: Pengantar Teori-teori Pemahaman Kontemporer (Jakarta: The Ford Foundation, 1999). 
konflik agama dan radikalisme? bagaimana posisi Walisongo dan Kiai Ciganjur?

\section{B. Pembahasan}

\section{Islam Formalis}

Islam mengajarkan kebaikan dan keutamaan hidup dan memerintahkan berjihad untuk berperang karena alasan berikut: mempertahankan keyakinan dan kepercayaan dari upaya pelarangan pihak-pihak yang lain dan mempertahankan harkat dan martabat kemanusiaan yang terkebiri dan terzalimi oleh kuasa tokoh agama dan kuasa tirani kekuasaan. Hal-hal yang terkait dengan kebaikan dan keutamaan hidup telah berjalan sesuai dengan perilaku keberagamaan umat Islam. Berbeda dengan prinsip nilai kebaikan dan keutamaan hidup ini, ajaran tentang jihad menjadi kawasan yang berubah makna. Ajaran tentang jihad menjadi teks untuk penguatan kepentingan ideologis dan politis. Kepentingan ideologis dan politis ini yang mendorong adanya gerakan revolusioner dan radikalisme Islam. Model keberagamaan umat Islam yang menjadi lahan masuknya kepentingan ideologis dan politis adalah paham Islam formalis. Karenanya, banyak kajian dan penelitian yang mengkritisi paham Islam formalis di tengah konflik keberagamaan dan ideologi berbasis agama.

Fenomena ini didukung problem pemahaman para pengikut Islam formalis yang bersikap memilih bersikap secara eksklusif terhadap pemahaman dan keyakinannya. Akhirnya para pengikut Islam formalis di satu sisi sangat teguh memegang ajaran Islam yang terkait dengan gerakan komunal, namun di sisi yang lain mengabaikan ajaran yang menegaskan tentang perlunya memberikan penghargaan terhadap perbedaan pemahaman dan keyakinan kepada yang lain. (Q.S. al-Kafirun [109]: 1-6). Beberapa keberhasilan penyusupan kelompok Islam ideologis pada Islam formalis berlangsung dalam gerakan politik sayap kiri pada masa Revolusi Perancis (1787-1789) dan gerakan radikalisme agama yang berlangsung pada pertengahan 1980-an yang menentang paham modernitas dan sekularisme. Gerakan radikalisme agama 
Islam menentang paham modernitas dan sekularitas berlanjut hingga sekarang.

Jika kita baca secara historis, maka dapat menjadi simpulan, bahwa gerakan Islam pada masa Nabi bertujuan untuk mempertahankan keyakinan. Gerakan Islam pada masa sahabat bertujuan untuk mempertahankan tradisi keberagamaan umat Islam. Selain tujuan ini, konflik pada masa sahabat adalah konflik kesalahpahaman antara para sahabat. Konflik gerakan Islam pada masa tabi'in terkait dengan perebutan kuasa pemahaman terhadap teks kewahyuan dan hadis Nabi Muhammad. Adapun konflik gerakan Islam pada masa tabi'it tabi'in tentang menguatnya aliran-aliran baru dalam Islam versus aliran Islam yang lain dan gerakan Islam versus perebutan kekuasaan pemerintahan Islam. Sebagaimana yang ditandai revolusi Perancis dan pada masa pertengahan tahun 1980-an, perkembangan konflik gerakan Islam pada masa pencerahan ini justru berupaya ingin mendudukkan Islam pada posisi yang anti kemanusiaan dan anti modernitas. Ironisnya, paham kelompok Islam formalis ini mudah dibajak kelompok ideologis dan politis untuk melegitimasi gerakan anti kemanusiaan dan anti modernitas. Artinya, ajaran formal agama akan memudahkan paham individu dan paham gerakan komunalisme berlindung simbol gerakan atas nama ajaran suci.

Fenomena inilah yang mendasari kemunculan isme-isme baru di tengah kehidupan umat beragama. Isme baru dalam keberagamaan menguatkan agama untuk menjadi simbol formal yang menghalalkan kepentingan individu dan kepentingan komunal. Jadi, yang tepat untuk melihat fenomena keberagamaan umat Islam, bukan siapa atau gerakan komunal seperti apa beragama apa? Sebab, pandangan ini akan menjadikan agama Islam sebagai bentuk kulit luar yang menutupi kepentingan individu dan gerakan komunal. Sementara itu, ajaran yang hakiki tentang prinsip keutamaan dan jihad yang benar akan mudah dikaburkan oleh simbol kehendak kepentingan dan visi gerakan komunalisme agama. Fenomena konflik keberagamaan umat Islam ini memuncak di tengah perebutan kekuasaan yang menjadikan formalitas agama sebagai bentuk legitimasi kulit 
luar untuk menyembunyikan kehendak kuasa individu dan gerakan komunal.

Simbol atau formalitas agama yang terkebiri oleh kuasa individu (permodalan) dan gerakan komunal ini telah melahirkan kritik Karl Mark terhadap agama sebagai candu yang sama berbahayanya seperti narkotika. Formalitas agama yang ditemukan pada gerakan Islam formalis menekankan pada: Pertama, model pemahaman secara literer. Kedua, model pemahaman yang menolak lokalitas tradisi atau budaya kecil. Ketiga, model pemahaman yang menjadikan Islam sebagai agama formalitas atau simbol formal hukum negara. Keempat, model pemahaman terhadap kebenaran tunggal.

Jejak-jejak Islam formalis ini sudah berkembang sebelum kemunculan gerakan Islam radikal dunia, namun berubah menjadi negatif setelah kemunculan gerakan radikal di tengah keberagamaan umat Islam. Hal ini terjadi, karena setiap simbol agama akan mudah menjadi menarik simpati bagi yang belum memahaminya. Karenanya, beberapa ulama tidak menggunakan Islam sebagai simbol formalis gerakan, dengan tujuan untuk menghindarkan model keberagamaan yang justru memperkeruh pemahaman tentang Islam. Islam merupakan agama yang mengajarkan prinsip keutamaan yang bebas dari kepentingan yang ingin menjadikan Islam sebagai ideologi kepentingan kehendak kuasa. Islam secara formalis akan membuka peluang ideologi-ideologi dunia memanfaatkannya sebagai kendaraan sifat radikalisme pada semua ideologi dunia.

Faktor eksternal yang memengaruhi mental para pengikut paham Islam formalis akan menyesuaikan arus utama gerakan yang hanya mengacu pada simbolisme. Acuan ini akan menentukan kehendak, keinginan, tindakan, tujuan, usaha, perasaan, sifat dan karakter, bentuk kesadaran diri, amarah, dan merasa menentukan untuk mudah menginternalisasikan nilai yang ada di lingkungan eksternal yang membentuknya. Jika faktor eksternal ini menjadi modeling dalam radikalisme agama, maka makna keutamaan dan kemanusiaan akan terselimuti oleh riya-riya ajaran suci dalam keberagamaan. Sehubungan dengan mentalitas teroris ini bisa 
disebabkan oleh model pemahaman terhadap teks keagamaan yang bersifat formalis radikal. Misalnya, pada kasus konflik berdarah Perang Salib. Konflik ini sudah menjadi pemahaman komunal keberagamaan secara formalis radikal, sehingga secara otomatis menjadikan pihak lain sebagai musuh. ${ }^{4}$

Gerakan Islam formalis radikal sebagai klasifikasi yang kedua ini disebabkan oleh beberapa hal berikut ini. Pertama, adanya ideologi yang membatasi pemahaman terhadap teks kewahyuan. Kedua, model menjadikan agama sebagai justifikasi diskursus kesempurnaan gerakan radikal. Teks kewahyuan yang sering dijadikan untuk menyokong diskursus gerakan radikal adalah Q.S. al-Ma'idah [5]: 3. Prinsip ini yang mendorong semangat perlawanan terhadap kehendak kuasa yang dianggap zalim. Konteks yang terlupakan dari pemahaman ini adalah kategori zalim. Jika zalim hanya diukur dari bentuk adanya kesamaan atau perberbedaan dengan pemahaman satu kelompok, berarti telah menjadikan makna zalim sebagai bentuk pemahaman Islam yang hanya untuk kepentingan formal (Islam formalis).

\section{Islam Lokalis}

Islam lokalis yang penulis maksudkan dalam sub judul ini adalah wajah gerakan Islam yang bersifat ramah terhadap kearifan lokal. ${ }^{5}$ Gerakan ini memahami nilai universalitas sebagai nilai dasar etika kehidupan yang bisa ditemukan pada semua kawasan kehidupan manusia. ${ }^{6}$ Misalnya, di tengah kehidupan modern dan kehidupan masyarakat adat atau lokal, gerakan Islam lokalis berusaha menjaga keamanan ajaran suci agama Islam bebas dari pembajakan kehendak ideologis dan politis. Kerangka berpikir gerakan Islam lokalis didasarkan pada bangunan risalah kenabian yang selalu tidak terlepas dari pengawasan sistem kehendak

${ }^{4}$ Ira M. Lapidus, Sejarah Sosial Umat Islam (Bagian Ketiga), terj. Ghufron A. Mas'adi (Jakarta: Raja Grafindo Persada, 1999), hlm. 11-30.

${ }^{5}$ Ubaidillah Achmad dan Yuliyatun Tajuddin, Suluk Kiai Cebolek dalam Konflik Keberagamaan dan Kearifan Lokal (Jakarta: Prenada Media, 2014).

${ }^{6}$ H.M. Nasruddin Anshoriy CH, Kearifan Lingkungan dalam Perspektif Budaya Jawa (Jakarta: Yayasan Obor Indonesia, 2008). 
kuasa yang hegemonik dan bersikap sewenang-wenang. ${ }^{7}$ Sebagai contoh, nilai universal yang secara berkelanjutan berlangsung dalam kisah kenabian sejak Nabi Dawud, Nabi Yusuf, Nabi Musa, Nabi Isa, hingga Nabi Muhammad berupa ketauhidan, kemanusiaan, keadilan, dan persamaan.

Sehubungan dengan perspektif kehendak kuasa yang berpikiran ideologis dan politis, ${ }^{8}$ maka perlu berhati-hati menguatkan peran risalah suci kenabian. Jika tidak hati-hati menerapkan nilai keutamaan, maka akan memunculkan gerakan pembajakan yang akan mengaburkan misi suci risalah kenabian. Bersamaandengan nilaiuniversalyang diusungolehparanabi,maka seseorang bisa lebih sederhana dan ramah terhadap lingkungan atau budaya lokal. Model implementasi risalah kenabian ini menjadi prinsip yang terus bertahan melalui regenerasi kenabian melalui perpaduan paradigma universalitas risalah kenabian dan melalui pengakuan para nabi terhadap tradisi-tradisi masyarakat yang sudah menjadi bentuk ajaran kearifan lokal. Allah dan Nabi Muhammad juga selalu mengingatkan, setiap perbuatan tentang kebaikan harus dilakukan dengan kehendak hati dan bukan dengan cara memproklamirkan kebaikan kepada publik. Sudah banyak contoh, kekerasan yang mengatasnamakan gerakan agama atau gerakan Islam radikal akan mudah menodai kesucian Islam. ${ }^{9}$ Noda ini akan selalu muncul dari orang yang ingin memanfaatkan agama Islam sebagai Islam formalis.

Fenomena ini disadari oleh para nabi dalam tradisi kenabian, sehingga setiap nabi menunjukkan model keberagamaan yang mempertahankan nilai universalitas, namun juga ramah terhadap kondisi lokal subjek dampingan atau individu dalam sebuah masyarakat. Misalnya, pandangan Nabi Shaleh terhadap hewan

${ }^{7}$ Deddy Ismatullah dan Asep A.S. Gatara, Imu Negara dalam Multi Perspektif: Kekuasaan, Masyarakat, Hukum, dan Agama (Bandung: Pustaka Setia, 2007), hlm. 207.

${ }^{8}$ Firmansyah, Marketing Politik antara Pemahaman dan Realitas (Jakarta: Yayasan Obor Indonesia, 2008), hlm. 132.

'Ahmad Syafi'i Ma'arif, "Nur Huda Ismail dan Karyanya, Sebuah Pengantar", dalam Nur Huda Ismail, Temanku Teroris: Saat Dua Santri Ngruki Menempuh Jalan yang Berbeda (Jakarta: Penerbit Hikmah, 2010), hlm. xi-xii. 
unta yang harus dijaga dan tidak boleh disembelih merupakan contoh arti unta pada zaman Nabi Shaleh. Perspektif lokalis Nabi Shaleh berbeda dengan zaman Nabi Muhammad yang menjadikan unta sebagai binatang sembelihan untuk berkurban. Masih banyak contoh praktik lokalitas para nabi yang berbedabeda yang tidak bersifat simbolik dan formalistik, namun tetap secara berkelanjutan tidak melupakan universalitas keutamaan hidup. Sebagai contoh, penghargaan Nabi Muhammad terhadap kearifan lokal tentang puasa dan tata cara merespons kebersihan serta model pengenalan terhadap agama tauhid. Pernah terjadi kasus pencurian, sementara itu Nabi memerinthkan agar yang telah melakukan pencurian untuk diadili sesuai dengan hukum secara adat.

Dalam konteks keberagamaan abad modern, tidak berbeda dengan zaman tradisi kenabian. Model keberagamaan sekarang ini juga dihadapkan pada tradisilokal yangmembutuhkan penyesuaian dengan nilai universalitas tradisi kenabian. ${ }^{10}$ Adanya fenomena radikalisme agama, karena adanya pemahaman dan sikap yang bersifat atau berbentuk formal yang mengabaikan penghargaan terhadap tradisi lokal. Oleh karena itu, umat beragama Islam secara pemahaman dan perilaku tidak bisa hanya mengacu pada hukum formal atau ajaran formal agama Islam. Sebab, secara formalitas menjalankan agama, seseorang berhadapan dengan tradisi lokal yang bersimetris dengan model keberagamaan anak zaman. Benih-benih radikalisme agama disebabkan oleh keterbatasan menentukan pilihan terhadap model pemahaman dan terhadap sikap keberagamaan. Imajinasi yang tergambar berupa sikap dan perilaku kekerasan terhadap mereka yang berbeda pilihan. Gejala psikologis model keberagamaan secara formalis ini juga akan menjadi sasaran mereka yang merancang ideologi dan sistem politik melalui sakralitas formalitas agama. Karenanya, Islam lokalis merupakan Islam yang tidak hanya menganggap penting tradisi lokal, namun juga menganggap berarti sisi manusiawi pihak yang lain atau tradisi atau budaya kecil dari pemikiran pihak lain.

${ }^{10}$ John L. Esposito, Masa Depan Islam, terj. Eva Y. Nukman dan Edi Wahyu (Bandung: Mizan 2010), hlm. 112. 
Filosofi makna wahyu tidak hanya yang berupa teks secara formal, namun masih banyak lapisan-lapisan kawasan teks kewahyuan yang memerlukan kejian, penelitian, dan penghargaan. Di antara lapisan-lapisan kawasan teks kewahyuan ini ada tradisi kecil yang menjadi fondasi bangunan nilai universal atau tradisi kenabian yang pernah berkembang pada zaman pelaku risalah kenabian.

Dalam konteks gerakan sosial-keagamaan, Islam lokalis dapat dilihat dari model gerakan kaum Nahdliyyin. Gerakan kaum Nahdliyyin merupakan gerakan Islam yang lebih menunjukkan pandangan dan sikap berdasarkan pada prinsip toleran terhadap pihak lain, baik dengan mereka yang seagama maupun yang berbeda agama. Gerakan kaum Nahdliyyin bercorak keberagamaan yang sudah dikenalkan dalam pribumisasi Islam dan dilanjutkan oleh Kiai Ciganjur. Secara teologis, fikih, dan ilmu tasawuf, kaum Nahdliyyin memiliki persepsi sama, namun konteks politik berkecenderungan untuk berbeda-beda. ${ }^{11}$ Karenanya, dalam konteks politik, kaum Nahdliyyin memiliki pilihan partai berbeda-beda. Kaum Nahdliyyin merupakan kaum yang sangat mencintai Islam, namun tidak memandang Islam dari kulit luar saja. Kaum Nahdliyyin memiliki paradigma berpikir yang sudah terbentuk melalui gerakan keislaman dan memiliki komitmen pada kearifan lokal. ${ }^{12}$ Kaum Nahdliyyin juga mengakui keberadaan rasionalisme dan empirisme yang digunakan untuk mendukung teks suci kewahyuan. Dalam konteks keberagamaan, kaum Nahdliyyin telah dikenal sebagai kaum sarungan dan pecisan, namun menerima perkembangan ilmu pengetahuan dan teknologi. Dalam konteks sosial politik, kaum Nahdliyyin berprinsip terbuka menempatkan diri di tengah relasi kuasa kebijakan pemerintah dalam proses berintegrasi dengan masyarakat nasionalis. ${ }^{13}$

${ }^{11}$ PBNU, "Negara Menurut Ahlussunah wal Jama'ah", dalam Materi Musyawarah Nasional Alim Ulama dan Konferensi Besar Nabdlatul Ulama (Jakarta: PBNU, 2012), hlm. 193.

${ }^{12}$ Ahmad Syafi'i Mufid, Tangklukan, Abangan, dan Tarekat: Kebangkitan Agama di Jawa (Jakarta: Yayasan Obor Indonesia, 2006).

${ }^{13}$ Martin van Bruinessen, NU, Tradisi, Relasi-Relasi Kuasa, dan Pencarian Wacana Baru (Yogyakarta: Pustaka Pelajar, 1993); Martin van Bruinessen, Kitab Kuning: 


\section{Pribumisasi Islam Walisongo}

Istilah Walisongo merupakan bentuk tanda yang menandai keberadaan ulama yang masuk dalam hitungan jumlah kewalian yang berjumlah sembilan. Gelar ini memaknai tanda kewalian dalam kepribadian sosok yang mengendalikan (wali) lubangan sembilan (songo). Hal ini disesuaikan dengan kondisi tubuh manusia yang terdiri atas sembilan lubangan, yaitu dua lubangan mata, dua lubangan telinga, dua lubangan hidung, satu lubangan mulut, dua lubangan "depan-belakang". Manusia berkewajiban menjaga sembilan lubang ini, sehingga tidak terisi hal-hal negatif yang berbentuk materi yang indrawi atau nonmateri yang nonindrawi. Jika manusia tidak mampu menjaga lubangan sembilan ini dari hal-hal yang tercela, maka akan terjerumus dan jatuh pada jurang kenistaan. Menjaga lubangan sembilan ini merupakan ajaran penting yang menjadi jalan dan suluk kewalian Walisongo. Selain itu, pribumisasi Islam dilakukan dengan modal ketajaman para Walisongo melakukan silaturahim melalui pintu-pintu rumah sebagaimana model rumah yang dimiliki orang Jawa. ${ }^{14}$

Dalam konteks yang lain, Walisongo menjadi suatu gelar yang diberikan kepada sosok kesembilan nama besar yang diakui keilmuan dan kearifannya serta memiliki kasih sayang kepada sesama umat manusia. Keberadaan Walisongo telah menguatkan diri memasuki fase pencerahan di tengah masyarakat melalui visi peradaban Islam yang rạmatan li al'álamin. Karenanya, keberadaan Walisongo ini sangat dekat dengan rakyat kecil, kelas menengah desa dan kota, ${ }^{15}$ serta dekat dengan mereka yang berkuasa dalam sistem kerajaan masyarakat Jawa. Gelar wali ini diberikan oleh para ulama yang sezaman dengan kesembilan

\footnotetext{
Pesantren dan Tarekat (Bandung: Mizan, 1998).

${ }^{14}$ Jan Newberry, Back Door Java (Jakarta: Yayasan Obor Indonesia, 2013).

${ }^{15}$ Tipologi kelas menengah ini telah diuraikan dalam penelitian Gerry van Klinken, The Making of Middle Indonesia: Kelas Menengah di Kota Kupang, 1930-an 1980-an (Jakarta: Yayasan Obor Indonesia, 2015); dapat dilihat juga dalam beberapa kumpulan tulisan yang diedit oleh Gerry van Klinken dan Ward Berenschot, In Search of Middle Indonesia: Kelas Menengah di Kota-kota Menengah (Jakarta: Yayasan Obor Indonesia, 2015).
} 
ulama yang masuk dalam lingkaran Walisongo. Lingkaran Walisongo ini membuktikan darmanya kepada agama dan lingkungan masyarakat tanpa membeda-bedakan agama, ras, dan kesukuan. Lingkaran kekuatan kesatuan perspektif dan gerakan Walisongo mampu menjadi mediator yang menghubungkan antara pemimpin pemerintah dan rakyat di hadapan Allah.

Mengingat begitu dekatnya keberagamaan kesembilan wali ini dengan rakyat dan keteguhan pandangan dan sikap gerakan Walisongo pribumisasi Islam, ${ }^{16}$ maka ketika para pedagang Arab bersifat simbolik terhadap teks kewahyuan yang masih berbahasa Arab, Walisongo menyebarkan tradisi kenabian dengan tetap menghargai terhadap kearifan lokal. Walisongo merasakan simbolisasi gerakan keagamaan merupakan gerakan yang tidak relevan dengan tradisi kenabian dan masyarakat Jawa. Kondisi ini yang menguatkan model pribumisasi Islam di tengah masyarakat Jawa. Simbolisasi agama Islam atau yang disebut dengan Islamisasi hanya akan menimbulkan kontraproduktif upaya penguatan nilai luhur dan nilai keutamaan ajaran agama Islam. Simbolisasi agama yang membentuk gerakan Islam formalis radikal (islamisasi) akan mempersulit pribumisasi ajaran Islam. Hal ini juga akan menimbulkan ironisme gerakan keberagamaan, karena pelaku gerakan keagamaan yang tidak memahami nilai agama yang sudah ada di lingkungan masyarakat lokal. Walisongo tidak menginginkan model simbolik keagamaan yang menghilangkan hakikat ajaran keagamaan yang sudah berjalan baik di tengah lingkungan masyarakat lokal.

Sehubungan dengan prinsip Walisongo ini, telah mencerminkan penanaman nilai yang jauh dari simbolik keberagamaan. Makna dari semua suluk Walisongo menegaskan bahwa model formalisasi Islam radikal hanya akan menimbulkan kontradiksi pandangan dan keberagamaan masyarakat Jawa yang sudah menjunjung tinggi ajaran kenabian. Bukti masyarakat Jawa menjunjung ajaran kenabian dapat dipahami dari teks Hana Caraka, yaitu: pertama, hana caraka (ada seorang utusan

${ }^{16}$ Alwi Shihab, Islam Inklusif (Bandung: Mizan, 1998); Ahmad Syafi'i Ma'arif, Membumikan Islam (Yogyakarta: Pustaka Pelajar, 1996). 
Allah); kedua, data shawala (seorang utusan yang menerima segala risiko perjuangan); ketiga, pada jayanya (yang sama-sama ingin mengangkat harkat dan martabat kemanusiaan, keadilan, dan persamaan); keempat, maga batanga (semua rasul dan para nabi dan umat manusia akan sama-sama memenuhi panggilannya). Karenanya, antara sesama umat manusia harus berprinsip yang sama, berupa rasa ringan bisa diangkat bersama-sama dan rasa ringan bisa dijinjing secara bersama-sama.

Jadi, simbolisasi agama atau menjadi Islam formalis radikal merupakan cita-cita yang tidak jelas tujuannya. Fenomena Islamisasi ini akan mengundang bendera non Islam berkibar. Secara historis, Islam formalis radikal hanya akan melahirkan gerakan kekerasan atas nama Islam. Dalam memasuki fase pencerahan, Walisongo intens merambah dua jalur: jalur kultural dan struktural. Jalur pertama merupakan jalur masyarakat bertujuan untuk memperluas daya jangkau tentang pribumisasi Islam, seperti teks kemanusiaan, keadilan, dan persamaan. Jalur kedua merupakan jalur melalui struktural kekuasaan kerajaan yang berkembang pada zama Walisongo. Kedua jalur ini telah diisi dengan tata cara perdagangan, pernikahan, kesenian, dan kebudayaan. Banyak keluarga Walisongo yang menikah dengan keluarga raja dari Jawa, menikah dengan salah satu keluarga masyarakat. Dalam konteks perdagangan dan kesenian, Walisongo juga secara integratif bersama-sama masyarakat melakukan perdagangan dan kerja sama mengembangkan kesenian masyarakat Jawa.

Sehubungan dengan kesenian menunjukkan adanya integrasi Walisongo dengan kesenian lokal, sehingga banyak lakon pewayangan dan ketoprak yang mengambil tema tentang perjuangan Walisongo, khususnya Sunan Kalijaga dan penerusnya Kiai Cebolek (Kiai Ahmad al-Mutamakkin). Selama Walisongo melakukan pribumisasi Islam, juga pernah berkunjung ke beberapa kawasan kerajaan Islam Nusantara dan Arabia, bertujuan menghadiri serangkaian pertemuan yang membahas permasalahan umat manusia. Di tengah kehidupan masyarakat, pesan dan titah perjuangan Walisongo telah dipercaya oleh masyarakat luas, baik 
mereka yang terus terang dengan mengikuti ibadah mahdah yang diajarkan Islam maupun mereka yang tertarik dengan prinsip kebatinan dan keutamaan pandangan dan sikap Walisongo. Para raja di lingkungan kerajaan Jawa menjadikan Walisongo sebagai tokoh nasionalis yang memiliki tanggung jawab tinggi berbicara kedaulatan individu, masyarakat, dan kedaulatan sistem yang sudah menjadi pedoman masyarakat. Di tengah kebudayaan masyarakat Jawa, Walisongo dihadapkan persoalan bagaimana menjawab persoalan mereka yang terdiri atas multiagama. Pada masa-masa ini, Walisongo sanggup menyelesaikan karya kesenian yang agung yang dapat menjadi pedoman nilai-nilai keyakinan dan tradisi masyarakat Jawa.

Walisongo bisa menjadi raja mengganti kedudukan raja di kerajaan Jawa, namun tidak ada yang berupaya menduduki kursi kekuasaan. Hal ini membuktikan komitmen Walisongo menjaga lubangan sembilan dan tidak berminat pada hal-hal yang menjadi kehendak kekuasaan. Keberadaan Walisongo mampu mengorganisir kehendak kekuasaan raja jawa dan kehendak masyarakat dalam kesatuan sistem pemerintahan yang stabil dan menjaga nilai kemanusiaan, keadilan, dan persamaan. Jika terdapat konflik kerajaan dan dengan rakyat di lingkungan masyarakat, maka hal ini berada di luar mediasi Walisongo. Walisongo mempunyai pengikut dari berbagai keyakinan dan tradisi keberagamaan yang sudah menjadi kepercayaan masyarakat Jawa. Meskipun Walisongo bertarekat, namun karena kekuatan model pribumisasi Islam, maka yang tampak adanya perpaduan prinsip ajaran Islam dengan model seni dan budaya yang memuat kearifan lokal. Umumnya para pengikut Walisongo adalah mereka yang terpengaruh oleh kewaliannya, sehingga mereka akrab disebut masyarakat zaman kewalian. Para pengikut yang tergabung dalam suluk kewalian ini melancarkan gerakan yang ramah terhadap lingkungan sehingga membuat kesuksesan gerakan zaman kewalian membangun tradisi keberagamaan masyarakat Jawa.

Meski tidak terhitung dari delapan zona kebudayaan (peradaban Barat, Konfusius, Jepang, Islam, Hindu, Ortodoks 
Slavia, Amerika Latin, dan Afrika), ${ }^{17}$ kebudayaan Jawa memiliki sejarah yang penting dalam keyakinan dan hasil bumi. Walisongo merupakan sosok yang memiliki perspektif pembebasan dan gerakan pencerahan yang tidak mengabaikan kebudayaan kecil yang tidak dihitung dalam kebudayaan dunia ini. Model Walisongo merespons kebudayaan Jawa menunjukkan pribumisasi Islam merupakan bentuk penghargaan Walisongo terhadap kearifan lokal atau kearifan budaya-budaya kecil. Hal ini sekaligus menunjukkan modeling pribumisasi Walisongo yang merupakan bentuk kritik terhadap model Islam formalis-radikal. Islam formalis-radikal menjadikan Islam sebagai zona kebudayaan yang besar yang tidak boleh terpengaruh oleh budaya-budaya yang lain. Walisongo sudah memperhitungkan bahaya konflik antar raja (abad ke-17 sampai abad ke-18), konflik antar bangsa (abad ke-19 yang berlangsung sejak 1793), konflik antar bangsa, dan konflik dunia (abad ke-20) merupakan konflik antar ideologi yang sudah ingin dihindari oleh Walisongo.

Kepekaan terhadap perkembangan kebudayaan masyarakat dunia, Walisongo telah membangun paradigma pribumisasi Islam. Keberhasilan pribumisasi Islam bukan berarti persoalan umat Islam telah selesai, karena sekarang ini justru umat Islam dihadapkan pada puncak pencapaian peradaban Barat dengan prinsip ideologi kapitalisme. Fenomena perkembangan adanya puncak peradaban Barat melalui kapitalisme justru akan mengancam kerekatan peradaban Barat dengan peradaban lain. ${ }^{18}$ Penyebab adanya konflik antar kedua peradaban bisa disebut sebagai terorisme. Adapun pihak-pihak yang sedang mempertahankan adalah pihak yang bersikap secara manusiawi. ${ }^{19}$ Artinya, sikap mempertahankan hak kemanusiaan yang diserang dan dijadikan korban politik kehendak kuasa kelompok tertentu yang tidak bertanggung jawab secara kemanusiaan. Misalnya,

\footnotetext{
${ }^{17}$ Samuel Huntington, Benturan Antarperadaban dan Masa Depan Politik Dunia, terj. M. Sadat Ismail (Yogyakarta: Qalam, 2001), hlm. 10-12, 47-53.

${ }^{18}$ Konflik ini dapat dibaca pada paper tentang Agama dan Dialog Antarperadaban, ed. M. Nasir Tamara dan Elza Peldi Taher (Jakarta: Paramadina, 1996), hlm. 3-4.

${ }^{19}$ Marshall G.S. Hodgson, The Venture of Islam: Iman dan Sejarah dalam Peradaban Dunia, terj. Mulyadhi Kartanegara (Jakarta: Paramadina, 2002), hlm. 138-139.
} 
Tarekat Naqsyabandiyah di Asia Tengah yang menjadi penggerak perlawanan politik terhadap ekspansi Cina dan Rusia, Gerakan Padri, dan pemberontakan Diponegoro di Indonesia. Karenanya, teks terorisme tidak bisa hanya dipahami dari perspektif agama versus anti agama, namun juga dapat dipahami dari perspektif kejahatan individual atau kejahatan komunal yang berupaya menekan orang lain atau kelompok yang lain. Hal ini disebabkan oleh kejahatan kemanusiaan yang dilakukan kehendak kuasa dan kehendak kapital di tengah globalisasi dunia.

\section{Dinamisasi Islam Kiai Ciganjur}

Kiai Ciganjur dibesarkan dari tradisi NU. Ia dilahirkan di Desa Jombang, sebuah desa di daerah Jawa Timur. Di Jombang tempat Kiai Ciganjur dilahirkan, terdapat beberapa pesantren milik keluarga, kota ini tidak kalah maju dalam pendidikan agama dibanding di Timur Tengah. Perlu dicatat bahwa ada peristiwa politik nasional yang mewarnai pesantren yang berada di Jombang ini. Peristiwa politik nasional ini berlanjut dan membentuk isu penting tentang resolusi jihad, sehingga bisa memengaruhi cara berpikir kebangsaan santri, kaum terdidik di bidang keagamaan yang tinggal di beberapa pesantren di Indonesia, termasuk Kiai Ciganjur.

Kiai Ciganjurmerupakan sebutanuntuk K.H.Abdurrahman Wahid, biasa disebut Gus Dur. Penulis menyebut istilah ini untuk mendekatkan pembaca pada kawasan pergerakan Gus Dur yang berada di Ciganjur. Di Ciganjur ini, K.H. Abdurrahman Wahid melakukan gerakan kemanusiaan, pro demokrasi, dan menguatkan peran-peran organisasi NU dalam memberikan pencerahan kepada masyarakat pesantren dan bangsa Indonesia. Model keberagamaan Kiai Ciganjur dengan Walisongo memiliki kesamaan prinsip dan model gerakan. Yang membedakan dari gerakan ini adalah penggunaan istilah gerakan. Jika Walisongo menggunakan istilah pribumisasi Islam, Kiai Ciganjur memilih menggunakan istilah dinamisasi Islam. Artinya, menjadi ajaran suci Islam sebagai ajaran yang dinamis meliputi zaman dan perkembangan ilmu pengetahuan. Konteks dinamisasi gerakan ini juga bisa dihadapkan pada konteks meletakkan Islam di tengah 
lingkungan masyarakat, khususnya masyarakat Jawa, Indonesia, dan masyarakat dunia. Alasan Kiai Ciganjur tidak menggunakan model keberagamaan yang bersifat simbolik dan formalis, karena model keberagamaan yang seperti ini akan membuka peluang pihak yang lain untuk memanfaatkan legitimasi Islam menguatkan kepentingan ideologis dan politik.

Dari hasil pembacaan secara hermeneutik terhadap teks yang diatasnamakan pemikiran Kiai Ciganjur, menyimpulkan bahwa kegigihan Kiai Ciganjur melakukan dinamisasi bertujuan untuk menegakkan kemanusiaan dan keadilan yang merata bagi seluruh masyarakat Indonesia. ${ }^{20}$ Misalnya, berupa keadilan hak warga negara, keadilan hak di muka hukum, dan keadilan hak mempertahankan keyakinan. Setiap perjuangan akan menghadapi benturan politik, ekonomi, dan sosial. Karenanya, tugas para santri dalam menjaga hasil pribumisasi Islam harus bersikap dinamis dan mampu melakukan dinamisasi keberagamaan di tengah kepentingan berbagai kelompok kepentingan.

Dinamisasi Kiai Ciganjur hasil perenungan dan kedalaman pemahamannya untuk merespons ketegangan yang terjadi dalam menegakkan: Pertama, keadilan dan demokrasi di Indonesia. Nilai-nilai Islam dapat menjadi dasar bangunan demokrasi di Indonesia ini bukan simpulan yang mengada-ada. Simpulan ini pernah ditunjukkan oleh Qadri Azizy dalam paper bertema "Islam and The Implementation of Democracy in Indonesia". ${ }^{21}$ Kedua, menciptakan kerukunan antar Islam dan non Islam. Arah kedua perjuangan ini kerap berbenturan dengan kehendak kuasa dalam pemerintahan dan kehendak kuasa tokoh agama Islam. Karenanya, keberadaan Kiai Ciganjur sering mendapatkan kritikan dari penguasa pemerintahan dan para tokoh gerakan Islam formalis radikal di Indonesia. ${ }^{22}$ Kiai Ciganjur menganggap

${ }^{20}$ Frans M. Parera (ed.), Gus Dur Menjawab Perubahan Zaman (Jakarta: Kompas, 1999).

${ }^{21} \mathrm{~A}$. Qodri Azizy, "Islam and The Implementation of Democracy in Indonesia”, Makalah Seminar IAIN Walisongo Semarang, 5-8 November 2000.

${ }^{22}$ Shaleh Muh. Isre (ed.), Tuhan Tidak Perlu Dibela (Yogyakarta: LKiS, 2000); Ida Laode, "Pergaulan dan Identitas NU", Jurnal Ulumul Qur'an, Vol. VI, No. 5, 1995. 
konflik rakyat karena disebabkan ketidakadilan dan sikap anti demokrasi para elit kekuasaan. Adapun konflik keberagamaan karena disebabkan oleh ketidaksiapan umat Islam meleburkan formalitas agama melalui dinamisasi agama Islam di tengah lingkungan sosialnya.

Jejak intelektual Kiai Ciganjur dibedakan menjadi dua. Pertama, fase tradisional. Fase ini dimulai dari masa kelahiran dan lingkungan pendidikan pesantrennya. ${ }^{23}$ Kedua, fase liberal. ${ }^{24}$ Fase ini dimulai sejak ia meneguhkan diri terlibat dengan gerakan sosial keagamaan melalui organisasi NU dan keterlibatannya dengan aktivis pro demokrasi. Kedua fase ini dibuat berdasarkan perspektif dinamisasi pandangan dan sikapnya tentang Islam, isu-isu kemodernan, dan kebangsaan.

Kiai Ciganjur melakukan perluasan ide dan gerakan modernisasi dan dinamisasi melalui tradisi pesantren dan melalui media terbitan nasional dan beberapa jurnal ilmiah yang dikelola oleh para akademisi di lingkungan kampus perguruan tinggi umum di Indonesia. Gerakan modernisasi dan dinamisasi Kiai Ciganjur dimaksudkan agar umat Islam tidak terjebak pada istilah Islamisasi. Istilah gerakan pemikiran yang mengacu pada Islamisasi hanya menjadikan Islam sebagai bentuk simbol luar yang cenderung pada model Islam formalis radikal. Model ini membahayakan perkembangan pemikiran Islam dan gerakan Islam dalam visi dan misi pribumisasi Islam Walisongo. Model pemikiran dan warna gerakan Kiai Ciganjur seperti ini terbentuk setelah berhasil memadukan pemikiran tradisional dan liberal. Kiai Ciganjur menyadari pentingnya ilmu keislaman abad pertengahan yang dikaji di lingkungan masyarakat pesantren, namun juga tidak kalah penting belajar bidang Sejarah, filsafat, sosiologi, antropologi, dan ilmu-ilmu humaniora. Dalam perspektif Kiai Ciganjur, teks kewahyuan dan kajian abad pertengahan tidak

${ }^{23}$ Abdurrahman Wahid, "Pesantren dan Kesusastraan Indonesia", Kompas, 16 November 1973.

${ }^{24}$ Abdurrahman Wahid, "Agama dan Demokrasi”, Dian/Interfidei (Yogyakarta: Interfidei, 1994). 
akan dipahami dengan baik jika mengabaikan penguasaan disiplin ilmu-ilmu modern tersebut.

Dalam pemikiran Kiai Ciganjur dapat dipahami bahwa kajian ilmu keislaman dan keyakinan umat Islam itu searah dengan perkembangan materi tentang kemajuan ilmu dan pengetahuan dan gerakan kemanusiaan. Karena itu, para santri harus menguasai khazanah klasik dan ilmu modern. Belajar tentang Islam itu harus menyeluruh, baik Islam sebagai agama keyakinan maupun Islam sebagai yang membentuk pembebasan dan pencerahan kepada umat manusia. Islam sebagai keyakinan (iman) akan mencapai hakikat puncak kehidupan di hadapan Allah. Jika seseorang menjadikan agama hanya sebagai agama keyakinan yang mengabaikan pembebasan dan pencerahan tanpa batas agama, ras, dan suku, maka akan menjadi agama yang ekstrem, radikal, dan teroris. Karenanya, beragama Islam harus menempuh kedua-duanya: menempuh keyakinan yang suci dan mencerahkan manusia. Keyakinan dan sikap membebaskan umat manusia adalah fase terpenting yang diisi dengan sebaikbaiknya oleh para nabi dan penerus kenabian yang mencerahkan umat manusia, seperti Walisongo, para kiai pesantren, dan Kiai Ciganjur. ${ }^{25}$

\section{Menjaga Kelangsungan Nilai Islam}

Fenomena perkembangan Islam formalis dan Islam lokalis telah menunjukkan makna pembelajaran berikut ini: Islam formal atau Islam yang bersifat normatif ${ }^{6}$ merupakan identifikasi gerakan pemahaman terhadap Islam yang tidak terlepas dari ajaran Islam secara formal atau norma yang diajarkan dalam ajaran Islam. Kemunculan gerakan ini merupakan hasil dari konsekuensi sikap keberagamaan yang mereka pahami. Namun demikian, bersamaan dengan perkembangan keberagamaan di tengah arus

${ }^{25}$ Karel A. Steenbrink, Pesantren Madrasah Sekolah: Pendidikan Islam dalam Kurun Modern (Jakarta: LP3ES, 1974); lihat juga Ulil Abshor-Abdalla, "Humanisme Kitab Kuning: Refleksi dan Kritik atas Tradisi Intelektual Pesantren”, Jurnal Pesantren, Vol. IX, No. 1, 1992, hlm. 75-82.

${ }^{26}$ M. Amin Abdullah, Studi Agama: Normativitas atau Historisitas? (Yogyakarta: Pustaka Pelajar, 1999). 
perkembangan politik dan ekonomi dunia, formalitas ajaran Islam berubah menjadi dua pemahaman. Pertama, pemahaman tentang Islam yang disesuaikan dengan kepentingan ideologis dan politik, yang disebut dengan gerakan Islam formalis ${ }^{27}$ atau gerakan Islam radikalis. ${ }^{28}$ Islam formalis telah gagal mencegah masuknya penyusup yang menjadikan wajah Islam formalis sebagai gerakan komunalis atau gerakan ideologis yang mengatasnamakan Islam. ${ }^{29}$ Kedua, pemahaman tentang Islam yang didasarkan pada nilai kebenaran yang bersifat universal dan lokal. Pemahaman yang kedua ini sesuai paham Islam raḅmatan li al'álamin dan kearifan lokal (Islam Nusantara).

Sehubungan dengan kemunculan diskursus tentang kedua model pemahaman ini muncul konsep pribumisasi Islam dan dinamisasi Islam. Kedua konsep (pribumisasi dan dinamisasi Islam) ini merupakan model keberagamaan yang sesuai dengan konteks keindonesiaan. Istilah pribumisasi Islam menjadi tanda kemunculan Walisongo. Adapun istilah dinamisasi telah menandai kemunculan Kiai Ciganjur. Model keberagamaan ini bersamaan dengan cara dan startegi Walisongo yang dilanjutkan oleh Kiai Cebolek dan berkembang pesat pada masa pergerakan keberagamaan Kiai Ciganjur. ${ }^{30}$

Keunikan dari model keberagamaan Walisongo dan Kiai Ciganjur terletak pada kemampuan keduanya dalam merumuskan nilai universal dan nilai lokal ajaran Islam dalam konteks keindonesiaan. Misalnya, model kepiawaian keduanya dalam konteks memaknai istilah jihad dan kafir dalam aktivitas keberagamaan. ${ }^{31}$ Antara istilah jihad dan kafir memiliki makna

${ }^{27}$ Muhammad Adnan, Pengarub Ideologi Besar Dunia terhadap Indonesia dalam Era Global (Semarang: Memeo, 1997).

${ }^{28}$ Muhammad Arkoun, Membongkar Wacana, terj. Mashur Abadi (Surabaya: al-Fikr, 1999); M. Amin Abdullah, Studi Agama: Normativitas atan Historisitas? (Yogyakarta: Pustaka Pelajar, 1999).

${ }^{29}$ M. Masyhur Amin, Agama, Demokrasi, dan Transformasi Sosial (Yogyakarta: LKPSM, 1985).

${ }^{30}$ Abdullah A'la, "Kemenangan Gus Dur Angin Sejuk bagi Iklim Keagamaan di Indonesia”, Kompas, 22 Oktober 1999.

${ }^{31}$ Abdurrahman Wahid, Islam Anti Kekerasan dan Transformasi Nasional, terj. M. Taufiq Rahman (Yogyakarta: LKiS, 1998); Abdurrahman Wahid, Muslim di Tengah 
yang bersifat formal atau normatif, namun kedua istilah ini bisa diarahkan pada pemahaman yang mengacu pada Islam formalis dan mengacu pada Islam lokalis. Istilah jihad dan kafir perspektif Walisongo dan Kiai Ciganjur menekankan pada Islam lokalis. Alasan yang mendasar dari perspektif Walisongo dan Kiai Ciganjur yang mengacu pada Islam lokalis, karena untuk menjaga kelangsungan nilai Islam di tengah perkembangan kultur lokal. Alasan ini didasarkan pada pemahaman Walisongo dan Kiai Ciganjur, bahwa Islam itu memuat ajaran yang bersifat rạ̣matan li al-'alamin. Artinya, yang rahmatan li al-'alamin menjangkau semua budaya dan tradisi-tradisi lokal.

Sehubungan dengan perspektif Walisongo dan Kiai Ciganjur terhadap makna jihad dan kafir, keduanya tidak secara formal melakukan perlawanan kepada mereka yang berbeda agama dan keyakinan, namun memaknai jihad dan kafir sebagai bentuk perlawanan terhadap kehendak kuasa ketidakadilan dan kezaliman. $^{32}$ Model perlawanan terhadap ketidakadilan dan kezaliman yang dicontohkan melalui pribumisasi Walisongo dan dinamisasi Islam Kiai Ciganjur berupa mempertahankan harkat dan martabat kemanusiaan, menguatkan keyakinan di tengah komunitas kaum musyrik dengan tanpa melakukan pertentangan yang mengakibatkan pelanggaran terhadap hak asasi manusia, menguatkan nilai-nilai universal dan kearifan lokal, serta membela hak-hak minoritas dan masyarakat yang tertindas. ${ }^{33}$ Modeling Walisongo dan Kiai Ciganjur merekonstruksi makna jihad dan kafir ini bukan tanpa alasan. ${ }^{34}$ Dari seluruh teks normatif tentang jihad dan kafir, hanya beberapa ayat yang menegaskan untuk dilakukan perlawanan. Adapun yang lainnya diperbolehkan melakukan peperangan dengan mereka yang menjadi subjek

\footnotetext{
Pergumulan (Jakarta: Leppenas, 1981).

${ }^{32}$ Madjid Khadduri, Teologi Keadilan: Perspektif Islam (Surabaya: Risalah Gusti, 1999).

${ }^{33}$ Akh. Minhaji, "Hak-hak Asasi Manusia dalam Hukum Islam: Penafsiran Baru Tentang Posisi Minoritas Non Muslim”, Jurnal Ulumul Qur'an, Vol. V, No. 2, 1993, hlm. 16-31.

${ }^{34}$ Abdurrahman Wahid, "Hubungan Antaragama, Dimensi Internal dan Eksternalnya”, Dian/Interfidei, hlm. 3-12
} 
sebagai kafir dan menjadi objek makna jihad, yaitu ketidakadilan dan kezaliman. Hal ini didasarkan pada 241 bab tentang jihad pada kitab Șaḩiḩ al-Bukhari, 100 bab tentang jihad pada kitab Șabih Muslim, 115 bab tentang jihad pada Sunan at-Tirmiziri, 172 bab tentang jihad pada Sunan Abü Dawud, 48 bab tentang jihad pada Sunan an-Nasäri, dan 46 bab tentang jihad pada Sunan Ibn Majah. Selain kitab-kitab hadis, terdapat pula beberapa karya ulama tentang jihad, salah satu kitab yang paling penting adalah Kitäb al-Jihä yang ditulis oleh Imam Abu Abdurrahman Abdullah bin Mubarak al-Mirwazi. ${ }^{35}$

Dalam kitab fikih yang dibaca di pesantren yang memegang pribumisasi Walisongo dan dinamisasi Kiai Ciganjur ${ }^{36}$ ditemukan bab khusus tentang jihad yang berkonotasi perang. ${ }^{37}$ Jihad dalam arti perang ini karena untuk mempertahankan harkat dan martabat kemanusiaan. ${ }^{38}$ Dalam perspektif ilmu tasawuf yang dikaji di pesantren, istilah jihad justru melakukan usaha perlawanan terhadap musuh yang terdapat dalam diri sendiri. Secara spesifik, jihad bisa bermakna mujāhadah yang dapat dipahami sebagai usaha untuk mencurahkan kemampuan diri

${ }^{35}$ Istilah jihad berasal dari jubud atau jabd, bermakna kemampuan mengeluarkan sepenuh tenaga. Secara etimologis berarti kesukaran yang diselesaikan dengan sungguh-sungguh. Jihad bersinonim dengan kata al-masyaqqah (jerih payah), al-juhdu, at-țaqah (kekuatan), al-qital, dan al-barb. Istilah ini berbeda pengertian antara yang terdapat dalam ayat Makiyah dan Madaniyah. Dalam ayat Makiyah, istilah jihad dipahami sebagai kata $\bar{a}$ m. Adapun dalam ayat Madaniyah, istilah jihad yang berjumlah 26 kata ini dipahami sebagai kata yang bermakna qital (perang).

${ }^{36}$ Abdurrahman Wahid, "Pengembangan Fiqh yang Kontekstual", JurnalPesantren, No. 2, Vol. II, 1985.

${ }^{37}$ Jauhar Hatta Hasan (ed.), Islam Kebangsaan: Fiqh Demokratik Kaum Santri (Jakarta: Pustaka Ciganjur, 1999).

${ }^{38}$ Manfred Ziemek, Pesantren dalam Perubahan Sosial, terj. B.B. Sandjojo (Jakarta: P3M, 1986); Ulil Abshor-Abdalla, "Humanisme Kitab Kuning: Refleksi dan Kritik atas Tradisi Intelektual Pesantren”, Jurnal Pesantren, Vol. IX, No. 1, 1992, hlm. 75-82; Martin van Bruinessen, NU, Tradisi, Relasi-Relasi Kuasa, dan Pencarian Wacana Baru (Yogyakarta: Pustaka Pelajar, 1993); Martin van Bruinessen, Kitab Kuning: Pesantren dan Tarekat (Bandung: Mizan, 1998); Veeger K.J., Realitas Sosial: Refleksi Filsafat Sosial atas Hubungan Individu Masyarakat dalam Cakrawala Sejarah Sosiologi (Jakarta: Gramedia, 1993); Mark R. Woodward (ed.), Jalan Baru Islam: Memetakan Paradigma Mutakhir Islam Indonesia, terj. Hasan Ali Fauzi (Bandung: Mizan, 1998). 
melawan penyakit hati. Misalnya, hasud, riya, ujub, takabur, gad $a b$, dan sum'ah. Beberapa ayat yang menjelaskan tentang jihad di antaranya: Q.S. al-Ankabut [29]: 6, 8, dan 69; Q.S. al-Hajj [22]: 39-40; Q.S. al-Baqarah [2]: 190 dan 193; Q.S. al-Hijr [15]: 85; Q.S. an-Nahl [16]: 125; Q.S. an-Nisa' [4]: 95; Q.S. at-Taubah [9]: 41, 91, dan 93; Q.S. al-Anfal [7]: 15 dan 16.

Jadi, konsep pribumisasi Islam Walisongo dan dinamisasi Islam Kiai Ciganjur telah menguatkan visi peradaban Islam yang dibangun oleh Nabi Muhammad saw. ${ }^{39}$ Visi peradaban Islam adalah menjaga kelangsungan nilai ajaran Islam yang bersifat rahmatan li al-'alamin untuk semua budaya dan tradisi lokal. ${ }^{40}$ Sehubungan dengan adanya visi peradaban Islam, perspektif Walisongo dan Kiai Ciganjur menjadi lebih bermakna, bahwa Islam tergantung pada sifat wahidiyah Allah. Karenanya, ajaran Islam merupakan ajaran mengagungkan Allah dan memuliakan manusia yang juga menjadi altar terpuji untuk perjumpaan antara latifah Allah dengan latifah manusia atau antara latifah manusia dengan latifah Allah. Oleh karena itu, visi peradaban Islam adalah membentuk kesatuan relasional kekhalifahan antara Allah dan manusia ${ }^{41}$ dan meninggikan relasi unsur kosmologis yang menjadi kesatuan saling terkait antara Allah, manusia, dan alam. ${ }^{42}$ Relasi suci yang terikat pada visi peradaban Islam menjadi tanggung

${ }^{39}$ Ziaul Haque, Wabyu dan Revolusi, terj. E. Setiawati al-Khattab (Yogyakarta: LKiS, 2000); Marshall G.S. Hodgson, The Venture of Islam: Iman dan Sejarah dalam Peradaban Dunia, terj. Mulyadhi Kartanegara (Jakarta: Paramadina, 2002).

${ }^{40}$ Nurcholish Madjid, Memberdayakan Masyarakat, Menuju Negeri yang Adil, Terbuka, dan Demokratis (Jakarta: Paramadina, 1996); Nurcholish Madjid, Islam, Doktrin, dan Peradaban (Jakarta: Paramadina, 1992); Nurcholish Madjid, Dialog Keterbukaan: Artikulasi Nilai Islam dalam Wacana Sosio Politik. Kontemporer (Jakarta: Paramadina, 1997); Nurcholish Madjid, "Menuju Masyarakat Madani”, Jurnal Ulumul Qur'an, Vol. VII, No. 2, 1996, hlm. 51-55.

${ }^{41}$ Hassan Hanafi, at-Turäs wa at-Tajdid: min al-'Aquidah i ia as-Saurah (Libanon: Dār al-Fikr, 1988).

${ }^{42}$ Istilah sufistik ini secara mendalam dapat dibaca pada karya berikut ini: 'Abd al-Mun'im al-Hifni, Mu'jam Mustalaḥăt as-Súfyyah (Beirut: Dār al-Masirah, 1980); Abu al-Qasim 'Abd al-Karim Hawazin al-Qusyairi, ar-Risalah al-Qusyairiyyah fi $\mathrm{Tlm}$ at-Tașawnuf (Beirut: Dār al-Khair, t.t.); Abu Nasr 'Abdullah ibn Ali as-Sarraj, Kitāab al-Lumā' fi at-Tasawnuf (Leiden: E.J. Brill, 1914); Ali ibn Usman al-Hujwiri, The Kasyf al-Mabjub: The Oldest Persian Treatise on Sufism (New Delhi: Taj Company, 1982). 
jawab manusia. Jika manusia dengan penuh gigih menjaga relasi suci unsur kosmologis, maka Allah akan menjadi wakil manusia yang sekaligus akan menyelesaikan persoalan-persoalan yang dihadapi manusia. Kerelaan Allah sebagai penguasa langit dan bumi bersedia menjadi wakil manusia merupakan bentuk kecintaan dan keluhuran Allah yang meneguhkan sifat wahidiyahNya di hadapan manusia.

\section{Simpulan}

Penelitian ini menegaskan kemunculan Islam formalis dan Islam lokalis. Islam formalis dan Islam lokalis merupakan model keberagamaan yang mengacu pada normativitas ajaran Islam. Meskipun bersumber dari norma keislaman yang sama, antara keduanya memiliki model kontekstualisasi yang berbedabeda. Paham Islam formalis menjadikan teks agama sebagai simbol ideologi perlawanan terhadap mereka yang berbeda agama dan berbeda kepentingan ideologi dan politik. Dalam perkembangannya, Islam formalis sudah dipahami menjadi paham sebuah gerakan komunal yang memaksakan keyakinan kepada orang lain untuk mengikuti akar-akar pemahaman yang diyakininya (radikal). Islam formalis dikenal dengan istilah Islam radikal. Adapun Islam lokalis ingin menjadikan ajaran Islam sebagai sumber pencerahan dan pembebasan kepada umat manusia. Islam lokalis ingin menjadikan Islam sebagai ajaran universal yang bisa diterapkan secara lokal, bersifat rạmatan li al-áamin. Sehubungan dengan kedua paham yang berbeda ini, kehadiran Walisongo dan Kiai Ciganjur lebih menguatkan sistem kontekstualisasi Islam lokalis, bertujuan untuk memberikan penghargaan pada nilai kemanusiaan, keadilan, dan persamaan. Manusia tidak mempunyai hak apapun terhadap manusia yang lain, sehingga satu sama lainnya harus saling menghargai dan memberikan penghormatan yang setara dengan sesama manusia. Semua manusia memiliki hak yang sama untuk mendapatkan sifat wahidiyah Allah. Oleh karena itu, yang bisa dilakukan manusia di tengah konflik kemanusiaan dan kealaman adalah melakukan pencegahan agar tidak terjadi kerusakan yang lebih besar (dar'u al-mafasid muqaddamun 'ala jalbi al-mașälih). Konsep pencegahan 
ini bertujuan untuk menjaga hak kemanusiaan diri sendiri dan orang lain ${ }^{43}$ serta menjaga hak kealaman yang berlangsung dalam ekosistem.

Jadi, setiap manusia tidak mempunyai hak untuk menyiksa diri sendiri dan juga menyiksa orang lain, ${ }^{44}$ baik melalui penyiksaan secara langsung melalui tangan sendiri maupun melalui cara-cara yang tidak langsung, seperti melakukan pengrusakan terhadap unsur-unsur kealaman atau lingkungan yang lestari. Fenomena adanya perkembangan gerakan Islam radikal di Indonesia ini tidak terlepas dari kehendak ideologis dan politis yang mengedepankan pada kepentingan pribadi dan golongan. Halini dibuktikan dengan banyaknya kerja sama politik yang dilakukan secara transaksional pada hal-hal yang menjadi kepentingan personal dan kelompok sendiri. Banyak kasus gerakan radikal dan terorisme disebabkan oleh konflikideologi komunal dan politik. ${ }^{45}$ Fenomena radikalisme agama merupakan bentuk kehendak kuasa ideologis dan politis, yang dengan mudah akan memanfaatkan simbol agama untuk kepentingan ideologi komunal dan kehendak kuasa. ${ }^{46}$

${ }^{43}$ Thoha Hamim, "Islam dan Civil Society: Tinjauan Tentang Prinsip Human Rights, Pluralism, dan Religious Tolerance", Makalah Seminar, Pusat Informasi dan Kajian Islam IAIN Sunan Ampel, 1999; Albert Haurani, Arabic Thought in The Liberal Age (1798-1939) (USA: Cambridge University Press, 1995).

${ }^{44}$ Baharuddin Lopa, al-Qur'an dan Asasi Manusia (Yogyakarta: Dana Bakti Prisma Yasa, 1997).

${ }^{45}$ Samuel P. Huntington, Benturan Antarperadaban dan Masa Depan Politike Dunia, terj. M. Sadat Ismail (Yogyakarta: Qalam. 2001); Samuel P. Huntington, "Benturan Antarperadaban dan Masa Depan Politik Dunia", dalam Agama dan Dialog Antarperadaban, ed. M. Nasir Tamara dan Elza Peldi Taher (Jakarta: Paramadina, 1996); International Crisis Group Asia Report, Indonesia Backgrounder: Why Salafism and Terrorism Mostly Don't Mix, Southeast Asia/Brussels, 13 September 2004.

${ }^{46}$ Hassan Hanafi, "Asal-usul Konservatisme Modern dan Fundamentalisme", Jurnal Ulumul Qur'an, Vol. II, No. 7, 1989, hlm. 18-25; Hassan Hanafi, Agama, Ideologi, dan Pembangunan, terj. Shonhaji Shaleh (Jakarta: P3M, 1991). 
Ubaidillah Achmad

\section{DAFTAR PUSTAKA}

A'la, Abdullah, "Kemenangan Gus Dur Angin Sejuk bagi Iklim Keagamaan di Indonesia", Kompas, 22 Oktober 1999.

Abdullah, M. Amin, Studi Agama: Normativitas atau Historisitas?, Yogyakarta: Pustaka Pelajar, 1999.

Abshor-Abdalla, Ulil, "Humanisme Kitab Kuning: Refleksi dan Kritik atas Tradisi Intelektual Pesantren", Jurnal Pesantren, Vol. IX, No. 1, 1992.

Achmad, Ubaidillah dan Yuliyatun Tajuddin, Suluk Kiai Cebolek dalam Konflik Keberagamaan dan Kearifan Lokal, Jakarta: Prenada Media, 2014.

Adnan, Muhammad, Pengaruh Ideologi Besar Dunia terbadap Indonesia dalam Era Global, Semarang: Memeo, 1997.

Amin, M. Masyhur, Agama, Demokrasi, dan Transformasi Sosial, Yogyakarta: LKPSM, 1985.

Anshoriy CH, H.M. Nasruddin, Kearifan Lingkungan dalam Perspektif Budaya Jawa, Jakarta: Yayasan Obor Indonesia, 2008.

Arkoun, Muhammad, Membongkar Wacana, terj. Mashur Abadi, Surabaya: al-Fikr, 1999.

Azizy, A. Qodri, "Islam and The Implementation of Democracy in Indonesia", Makalah Seminar IAIN Walisongo Semarang, 5-8 November 2000.

Bruinessen, Martin van, Kitab Kuning: Pesantren dan Tarekat, Bandung: Mizan, 1998. , NU, Tradisi, Relasi-Relasi Kuasa, dan Pencarian Wacana Baru, Yogyakarta: Pustaka Pelajar, 1993.

Esposito, John L., Masa Depan Islam, terj. Eva Y. Nukman dan Edi Wahyu, Bandung: Mizan 2010.

Firmansyah, Marketing Politik antara Pemahaman dan Realitas, Jakarta: Yayasan Obor Indonesia, 2008.

Hamim, Thoha, "Islam dan Civil Society: Tinjauan Tentang Prinsip Human Rights, Pluralism, dan Religious Tolerance", Makalah Seminar, Pusat Informasi dan Kajian Islam IAIN Sunan Ampel, 1999. 
Hanafi, Hassan, "Asal-usul Konservatisme Modern dan Fundamentalisme", Jurnal Ulumul Qur'an, Vol. II, No. 7, 1989.

, Agama, Ideologi, dan Pembangunan, terj. Shonhaji Shaleh, Jakarta: P3M, 1991.

, at-Turäs wa at-Tajdid: min al-'Āiqidah ila as-Saurah, Libanon: Dār al-Fikr, 1988.

Haque, Ziaul, Wahyu dan Revolusi, terj. E. Setiawati al-Khattab, Yogyakarta: LKiS, 2000.

Haryatmoko, "Budaya Politik Santun dan Pluralisme”, Kompas, 2 Februari 2002.

, "Etika Politik dan Civil Society", Kompas, 5 Juni 2001. "Mencari Akar Fanatisme Ideologi, Agama, atau Pemikiran", Kompas, 20 Desember 2001.

Hasan, Jauhar Hatta (ed.), Islam Kebangsaan: Figh Demokratik Kaum Santri, Jakarta: Pustaka Ciganjur, 1999.

Haurani, Albert, Arabic Thought in The Liberal Age (1798-1939), USA: Cambridge University Press, 1995.

al-Hifni, 'Abd al-Mun'im, Mưjam Mustalaḥăt as-Süfiyyah, Beirut: Dār al-Masirah, 1980.

Hodgson, Marshall G.S., The Venture of Islam: Iman dan Sejarah dalam Peradaban Dunia, terj. Mulyadhi Kartanegara, Jakarta: Paramadina, 2002.

Howard, Roy J., Hermeneutika: Pengantar Teori-teori Pemahaman Kontemporer, Jakarta: The Ford Foundation, 1999.

al-Hujwiri, Ali ibn Usman, The Kasyf al-Mahjub: The Oldest Persian Treatise on Sufism, New Delhi: Taj Company, 1982.

Huntington, Samuel P., "Benturan Antarperadaban dan Masa Depan Politik Dunia", dalam Agama dan Dialog Antarperadaban, ed. M. Nasir Tamara dan Elza Peldi Taher, Jakarta: Paramadina, 1996. Benturan Antarperadaban dan Masa Depan Politik Dunia, terj. M. Sadat Ismail, Yogyakarta: Qalam, 2001. Benturan Antarperadaban dan Masa Depan Politik Dunia, terj. M. Sadat Ismail, Yogyakarta: Qalam. 2001.

International Crisis Group Asia Report, Indonesia Backgrounder: 
Ubaidillah Achmad

Why Salafism and Terrorism Mostly Don't Mix, Southeast Asia/Brussels, 13 September 2004.

Ismatullah, Deddy dan Asep A.S. Gatara, Ilmu Negara dalam Multi Perspektif: Kekuasaan, Masyarakat, Hukum, dan Agama, Bandung: Pustaka Setia, 2007.

Isre, Shaleh Muh. (ed.), Tuhan Tidak Perlu Dibela, Yogyakarta: LKiS, 2000.

Khadduri, Madjid, Teologi Keadilan: Perspektif Islam, Surabaya: Risalah Gusti, 1999.

Klinken, Gerry van dan Ward Berenschot, In Search of Middle Indonesia: Kelas Menengah di Kota-kota Menengah, Jakarta: Yayasan Obor Indonesia, 2015.

Klinken, Gerry van, The Making of Middle Indonesia: Kelas Menengah di Kota Kupang, 1930-an - 1980-an, Jakarta: Yayasan Obor Indonesia, 2015.

Laode, Ida, "Pergaulan dan Identitas NU", Jurnal UlumulQur'an, Vol. VI, No. 5, 1995.

Lapidus, Ira M., Sejarah Sosial Umat Islam (Bagian Ketiga), terj. Ghufron A. Mas'adi, Jakarta: Raja Grafindo Persada, 1999.

Lopa, Baharuddin, al-Qur'an dan Asasi Manusia, Yogyakarta: Dana Bakti Prisma Yasa, 1997.

Ma'arif, Ahmad Syafi'i, "Nur Huda Ismail dan Karyanya, Sebuah Pengantar", dalam Nur Huda Ismail, Temanku Teroris: Saat Dua Santri Ngruki Menempuh Jalan yang Berbeda, Jakarta: Penerbit Hikmah, 2010.

Membumikan Islam, Yogyakarta: Pustaka Pelajar, 1996.

Madjid, Nurcholish, "Menuju Masyarakat Madani”, Jurnal Ulumul Qur'an, Vol. VII, No. 2, 1996.

, Dialog Keterbukaan: Artikulasi Nilai Islam dalam Wacana Sosio Politik Kontemporer, Jakarta: Paramadina, 1997. , Islam, Doktrin, dan Peradaban, Jakarta: Paramadina, 1992.

, Memberdayakan Masyarakat, Menuju Negeri yang Adil, Terbuka, dan Demokratis, Jakarta: Paramadina, 1996. 
Minhaji, Akh., "Hak-hak Asasi Manusia dalam Hukum Islam: Penafsiran Baru Tentang Posisi Minoritas Non Muslim”, Jurnal Ulumul Qur'an, Vol. V, No. 2, 1993.

Mufid, Ahmad Syafi'i, Tangklukan, Abangan, dan Tarekat: Kebangkitan Agama di Jawa, Jakarta: Yayasan Obor Indonesia, 2006.

Newberry, Jan, Back Door Java, Jakarta: Yayasan Obor Indonesia, 2013.

Parera, Frans M. (ed.), Gus Dur Menjawab Perubahan Zaman, Jakarta: Kompas, 1999.

PBNU, "Negara Menurut Ahlussunah wal Jama'ah", dalam Materi Musyawarah Nasional Alim Ulama dan Konferensi Besar Nahdlatul Ulama, Jakarta: PBNU, 2012.

al-Qusyairi, Abu al-Qasim 'Abd al-Karim Hawazin, ar-Risălah al-Qusyairiyyah fi Tlm at-Tasannuf, Beirut: Dār alKhair, t.t.

Santana K., Septiawan, Menulis Ilmiah: Metodologi Penelitian Kualitatif, Jakarta: Yayasan Obor Indonesia, 2010.

as-Sarraj, Abu Nasr 'Abdullah ibn Ali, Kit̄ab al-Lumā' fí at-Tas. awnuf, Leiden: E.J. Brill, 1914.

Shihab, Alwi, Islam Inklusif, Bandung: Mizan, 1998.

Simanjutak, Bungaran Antonius, Metode Penelitian Sosial, Jakarta: Yayasan Obor Indonesia, 2014.

Steenbrink, Karel A., Pesantren Madrasah Sekolah: Pendidikan Islam dalam Kurun Modern, Jakarta: LP3ES, 1974.

Veeger K.J., Realitas Sosial: Refleksi Filsafat Sosial atas Hubungan Individu Masyarakat dalam Cakrawala Sejarah Sosiologi, Jakarta: Gramedia, 1993.

Wahid, Abdurrahman, "Agama dan Demokrasi”, Dian/Interfidei, Yogyakarta: Interfidei, 1994. " "Pengembangan Fiqh yang Kontekstual", Jurnal Pesantren, No. 2, Vol. II, 1985.

, "Pesantren dan Kesusastraan Indonesia", Kompas, 16 November 1973. Islam Anti Kekerasan dan Transformasi Nasional, terj. M. Taufiq Rahman, Yogyakarta: LKiS, 1998. 
Ubaidillah Achmad

Muslim di Tengah Pergumulan, Jakarta: Leppenas, 1981.

Woodward, Mark R. (ed.), Jalan Baru Islam: Memetakan Paradigma Mutakhir Islam Indonesia, terj. Hasan Ali Fauzi, Bandung: Mizan, 1998.

Ziemek, Manfred, Pesantren dalam Perubahan Sosial, terj. B.B. Sandjojo, Jakarta: P3M, 1986. 